\title{
PENGARUH TERPAAN TAYANGAN ANIMASI NUSSA OFFICIAL (CUCI TANGAN YUK) DI YOUTUBE TERHADAP PERILAKU IMITASI ANAK
}

\author{
Anasthya Luviani ${ }^{1}$, Santi Delliana ${ }^{2)}$ \\ ${ }^{1) 2}$ Ilmu Komunikasi, Fakultas Industri Kreatif, Institut Teknologi dan Bisnis Kalbis \\ E-mail : anastasia.santi@kalbis.ac.id
}

\begin{abstract}
ABSTRAK
Tayangan Nussa Official episode Cuci Tangan Yuk memberikan efek pada anak usia 4-5 tahun berupa meniru tingkah lakunya. Kegiatan mencuci tangan kini menyadarkan masyarakat akan pentingnya kesehatan. Dalam situasi wabah Covid-19 ini budaya mencuci tangan memakai sabun sangat diperlukan. Penelitian ini bertujuannya untuk mengetahui seberapa besar pengaruh terpaan tayangan animasi Nussa Official episode Cuci Tangan Yuk di YouTube terhadap perilaku imitasi anak usia 4-5 Kota Bekasi Utara. Metode yang digunakan adalah kuantitatif dengan jenis eksplanatif. Sampel pada penelitian ini adalah anak usia 4-5 tahun berjumlah 97 orang. Data diperoleh menggunakan kuesioner dengan skala likert, kemudian di analisis menggunakan uji regresi linier sederhana melalui software IBM SPSS 25. Penelitian ini menggunakan Teori Belajar Sosial. Hasilnya terdapat pengaruh terpaan tayangan animasi Nussa Official episode Cuci Tangan Yuk terhadap perilaku imitasi anak usia 4-5 tahun di Kota Bekasi Utara dengan koefisien korelasi sebesar 0,427 dengan persamaan regresi $\mathrm{Y}=46,328+0,797 \mathrm{X}$. Adapun koefisien determinasi $\mathrm{R}$ Square=0,182 yang berarti variabel terpaan tayangan animasi Nussa Official episode cuci tangan yuk mempengaruhi perilaku imitasi sebesar 18,2\%.
\end{abstract}

Kata Kunci: Perilaku imitasi;Anak usia dini;Terpaan tayangan;Youtube.

\section{PENDAHULUAN}

Berbicara mengenai media baru nampaknya tidak terlepas dari berbagai trend yang berkembang saat ini dan sudah berbasis teknologi komunikasi digital. New media melahirkan media sosial yang merupakan revolusi perkembangan baru dalam hal berkomunikasi dengan akses yang sangat bebas. Media sosial memiliki karakter dapat melibatkan orang lain untuk memenuhi keinginan dan kebutuhan mereka. Salah satunya membentuk rasa empati kepada siapapun, membuat hubungan atau relationship dengan siapa saja sebagai objek sosialitas, memberikan kepercayaan untuk dapat mengupdate apapun, dan media sosial juga dapat membuat kelompok media sosial secara fungsional seperti membentuk komunitas yang bisa meningkatkan kehidupan bersosial (Liliweri, 2018, p. 304).

YouTube salah satu sarana media sosial yang dapat bertukar informasi, mendapatkan hiburan yang dapat diakses secara mudah dan cepat. Konten hiburan yang berada di YouTube sangat beragam diantaranya fashion, gaya hidup, vlog, hingga film animasi. Film animasi ini masih menjadi salah satu tayangan yang dikategorikan banyak penggemarnya, karena film tersebut dapat ditonton oleh semua kalangan usia. Salah satunya Nussa Official (Nussa Official, 2019), tayangan animasi yang berisi konten edutainment yang bernilai positif tidak hanya memberikan hiburan tetapi ada pesan edukasi yang bisa didapatkan dan diterapkan oleh anak.

Nussa Official adalah salah satu film animasi yang aman ditonton oleh anak usia 4-5 tahun dengan menayangkan tentang agama islam, akidah-akidah dalam islam, doa sehari-hari, moral dan sopan santun terhadap orang tua, dan kerukunan antar adik dan kaka. Pada anak usia 4-5 tahun umumnya sangat rentan dengan apa yang dilihatnya secara langsung, karena anak pada usia tersebut lebih mudah untuk melakukan perubahan perilaku seperti meniru.

Menurut Sarwono (Wirawan, 1983, p. 89), Meniru adalah Melakukan sesuatu yang diperbuat oleh orang lain, belajar menyesuaikan tingkah laku yang dilihatnya. Kemampuan meniru dapat dilakukan melalui berbagai hal yang terjadi dalam kehidupan di segala usia, mulai dari orang tua, remaja hingga anakanak. Saat ini banyaknya khayalak yang mengakses YouTube sebagai media populer disemua kalangan, menjadikan khalayak dapat melakukan pilihan menonton sesukanya. Idealnya orang tua tidak menyadari tentang perilaku meniru yang dilakukan oleh anak, karena apapun yang ditiru berasal dari orang tua, lingkungan, bahkan media seperti televisi dan YouTube. Nussa Official bisa menjadi alternatif untuk orang tua yang ingin memberikan contoh berperilaku baik. Episode Cuci Tangan Yuk mengajarkan kebiasaan baik yang harus ditirukan 
dalam hal mencuci tangan memakai sabun. Karena dalam ajaran agama Islam dijelaskan bahwa Islam selalu mengutamakan Kebersihan. Dalam Hadist Riwayat Muslim ayat 223 berbunyi: "Kesucian Separuh dari Iman". Strategi dalam membentuk karakter anak adalah dimulai dengan mengajarkan kedisiplinan pada si kecil. Anak yang disiplin diri dapat menangani perasaan emosional yang tidak nyaman dan sehat. Tidak hanya itu, anak juga bisa mendapatkan manfaat dari pengajaran kedisiplinan (Nurhayati, 2020, p. 25).

Melalui tayangan Nussa Official, dapat mengajarkan anak-anak dalam menerapkan dikehidupan sehari-hari tentang pentingnya mencuci tangan. Adanya terpaan dari tayangan Nussa Official episode Cuci Tangan Yuk terhadap anak usia 4-5 tahun dijadikan contoh dan diterapkan secara langsung ketika mereka ingin mencuci tangannya sebelum makan dan sesudah bermain diluar. Terpaan yaitu status berapa kali khalayak menggunakan media agar lebih mudah memaparkannya pada pesan-pesan media. Mencuci tangan memakai sabun merupakan cara yang efektif dilakukan oleh manusia sebagai tindakan usaha agar terhindar dari berbagai kuman penyakit. Setiap tahun 3,5 juta anak di dunia meninggal karena penyakit diare sebelum mereka mencapai usia lima tahun dan mengalami ISPA (infeksi saluran pernafasan akut). Maraknya pandemi Covid-19 membuat khawatir para orang tua terutama anak usia 4-5 tahun, karena menyebabkan gangguan pernafasan akut yang mengakibatkan kematian penderitanya melalui batuk, sentuhan tatap muka, dan air liur. Dari tayangan animasi Nussa: Cuci Tangan Yuk sangat membantu orang tua dalam mendapatkan inspirasi untuk mengajarkan anak-anak usia 4-5 tahun supaya sebelum makan dan sesudah mainan harus mencuci tangan terlebih dahulu, karena tangan yang kotor penyebab bersarangnya penyakit, dengan diberikannya pemahaman maka anak dapat merespon dan mengingat hal positif yang akan dilakukannya jangka panjang.

Berdasarkan latar belakang diatas, maka tujuan dari penelitian ini untuk melihat seberapa besar pengaruh terpaan tayangan animasi Nussa Official episode cuci tangan yuk di YouTube terhadap perilaku imitasi anak usia 4-5 tahun di Kota Bekasi Utara.

\section{METODE}

\section{Tradisi Penelitian Komunikasi}

Penelitian ini menggunakan tradisi sosiopsikologis yang menganggap individu sebagai makhluk sosial dalam kehidupan sehari-hari yang membutuhkan orang lain. Menurut (Littlejohn, S. W dan Foss, 2018, p. 423) manusia dengan sangat mudah terpengaruh dan menerima pesan-pesan dari media, dikarenakan opini masyarakat terbentuk sangat kuat oleh adanya media.
Pada tradisi sosiopsikologis memahami berbagai kondisi situasi sosial pada kepribadian dalam menilai sifat seseorang. Berorientasi pada kognitif dengan memandang bagaimana manusia mengolah informasi yang diterimanya (Morrisan, 2010, p. 48). Terdapat tiga cabang aspek penting dalam tradisi sosiopsikologis, yaitu perilaku, kognisi, dan biologis. Dalam penelitian ini aspek kognitif adalah aspek yang digunakan, dimana aspek ini berkonsentrasi pada bagaimana seseorang mendapatkan, menyelamatkan, dan mengolah informasi tentang perilaku orang tersebut.

\section{Teori Belajar Sosial (Social Learning Theory)}

Pada tahun 1986, Albert Bandura adalah seorang tokoh bernama Teori Pembelajaran Sosial. Teori ini merupakan pengembangan dari ide pembelajaran imitatif oleh Miller dan Dollar. Albert Bandura dikenal sebagai seorang pakar psikolog yang memiliki Teori Belajar Sosial. Anak menunjukkan perilaku agresif yang ditirukan dari orang dewasa secara serupa hal ini merupakan eksperimen dari Bobo Doll. Bandura menekankan hal penting yang sangat menegaskan pentingnya mempengaruhi manusia dengan proses belajar melalui pengamatan yang biasa disebut Observational Learning meniru melalui pengamatan terhadap perilaku model. Menurut Bandura yang di kutip oleh (Bandura, 1997, p. 5) kebanyakan orang belajar secara selektif dengan mengamati dan mengingat perilaku orang lain. Teori pembelajaran sosial berpendapat bahwa manusia meniru tingkah laku yang dilihatnya dan proses peniruan berlangsung dalam dua cara yang berbeda, yaitu imitasi dan identifikasi (Morrisan, 2010, p. 98). Menurut Bandura dalam proses belajar sosial (Husamah, Yuni Pantiwati, Arina Restian, 2018, pp. 109-110), Dasar kognitif dalam proses belajar dapat membaginya dalam empat tahap:

- Atensi/Minat: tahap ini mempelajari dan mengamati peristiwa peniruan mulai dari melihat kejadian yang menarik dari media.

- Retensi/ Mengingat: kemampuan merekam dan menyimpan informasi penting dari proses belajar, Sebagai penyandian secara verbal dari yang mereka amati

- Reproduksi Gerak: kemampuan mempelajari suatu tingkah laku, dan mengulangi gerakan yang ditirunya sebagai proses adanya umpan balik.

- Motivasi: dorongan yang timbul secara sadar atau tidak untuk mencapai suasana kebanggan terhadap diri sendiri.

\section{Komunikasi}

Menurut Lasswell, proses komunikasi mengacu pada konten media oleh komunikator kepada komunikator, yang memiliki efek tertentu (Effendy, 2009, p. 10). Khomsahrial, (2016, p. 7) penyampaian pesan atau gagasan dari suatu pemikiran yang 
diberikan oleh orang lain untuk bertukar informasi dan berinteraksi dengan orang lain. Dalam berkomunikasi tidak hanya memberikan informasi saja tetapi ada unsur lain seperti pertukaran informasi, fikiran, pendapat dari satu orang kepada orang lain. Dalam berkomunikasi tidak hanya memberikan informasi saja tetapi ada unsur lain seperti pertukaran informasi, fikiran, pendapat dari satu orang kepada orang lain. Komunikasi adalah transmisi pesan komunikator kepada komunikator dengan simbol untuk memudahkan proses komunikasi. Komunikasi dapat menggunakan media dalam situasi tertentu untuk menjangkau area yang menantang dan audiens yang luas. Dengan komunikasi, seseorang harus dapat mempengaruhi perilaku, menawarkan pendapat, atau mengubah perilaku seseorang atau beberapa orang, untuk mencapai dampak tertentu (Rinawati, 2017).

\section{Terpaan Media}

Terpaan media menurut Kriyantono (2006, p. 209) Eksposur media adalah kegiatan mendengarkan, melihat, dan membaca media massa atau mengalami dan memperhatikan pesan individu atau kelompok. Menurut Bovee dan Arens dalam Kriyantono (2006), Eksposur media mengacu pada jumlah orang yang melihat program di media (Bovee \& Arens, 1995, p. 445). Eksposur media dapat digambarkan sebagai suatu kondisi di mana orang dihadapkan pada konten media atau bagaimana konten media menjangkau khalayak.

Penggunaan media terdiri dari jumlah waktu yang dihabiskan untuk media yang berbeda, jenis konten media yang dikonsumsi, dan hubungan yang berbeda antara konsumen individu dan konten media yang dikonsumsi atau dengan media secara keseluruhan. Paparan media adalah jumlah informasi, termasuk frekuensi, durasi, dan intensitas, yang diperoleh media. Untuk mengukur terpaan media dari tayangan animasi Nussa Official episode cuci tangan yuk, dapat menggunakan ukuran terpaan media, sebagai berikut (Kriyantono, 2016, p. 66):

- Frekuensi adalah jumlah pengulangan perilaku. Anda dapat menonton acara animasi di Youtube dengan frekuensi yang berbeda, bisa setiap hari, seminggu sekali, atau bahkan sebulan sekali, tergantung orangnya.

- Durasi atau lamanya penayangan untuk mengetahui berapa lama (jam) khalayak mengikuti program.

- Intensitas adalah proses mental ketika rangsangan atau rangkaian rangsangan dibuat peka untuk melemahkan rangsangan.

\section{Media Massa}

Menurut (Tamburaka, 2012, p. 13) dalam proses penyebaran informasi yang melibatkan banyak orang, media massa merupakan sarana penyampaian komunikasi dan informasi kepada masyarakat luas. Dapat disimpulkan bahwa media massa bersifat heterogen dan merupakan cara untuk menyampaikan komunikasi dan informasi secara simultan dari komunikator kepada komunikator.

\section{New Media}

Teknologi yang paling umum dijelaskan dalam New Media adalah media digital yang menggunakan internet online, bersifat interaktif dan fleksibel, dapat diakses secara pribadi atau publik. TV, film, majalah, buku, atau publikasi berbasis kertas bukanlah media baru. Namun kombinasi teknologi telekomunikasi, teknologi komputer, dan teknologi media massa merupakan konvergensi media baru (Fachruddin, 2011, pp. 36-37). McQuail menjelaskan dalam buku Mass Communication Theory bahwa New Media dan New Media adalah media digital dengan teknologi komunikasi internet yang menyampaikan pesan sekaligus, secara menyeluruh, dan personal sebagai media komunikasi. Menurut McQuail, interkoneksi, akses ke khalayak individu sebagai penerima dan pengirim pesan, interaktivitas mereka, penggunaan yang berbeda sebagai karakter terbuka, dan sifat selanjutnya adalah fitur utama dari media baru (Cangara, 2015, p. 30).

\section{Tayangan Animasi}

Menurut (Munir, 2012, p. 317) Animasi komputer digunakan untuk membuat gerakan di layar. Tampilan 2-D atau 3-D yang menciptakan ilusi gerakan. Tayangan dapat diartikan sebagai sesuatu yang ditampilkan oleh film, berita, hiburan, dan sebagainya kepada khalayak melalui sarana elektronik, di mana audio visual yang dapat dilihat dalam hal ini adalah YouTube. Sedangkan animasi dapat menjelaskan suatu konsep atau proses yang sulit dijelaskan oleh media lain. Animasi itu sendiri memiliki daya tarik estetika agar terlihat menarik dan menarik. Efek ini adalah film dengan latar waktu yang terdiri dari gambar yang sempurna dan dapat ditampilkan dalam berbagai cara, seperti film atau program video. Menurut Reiber (1994) dalam (Munir, 2012, p. 317), Kata latin "anima" adalah animasi yang berarti jiwa, hidup dan roh. Selain itu, kata animasi juga berasal dari kata animasi yang diaktifkan oleh akar kata anime. Animasi biasanya merupakan kegiatan mengaktifkan atau memindahkan benda mati. Benda mati ini membawa dorongan, kekuatan, antusiasme dan emosi untuk hidup.

\section{YouTube}

Menurut (Adi, 2009, p. 58) adalah situs web video yang menyediakan informasi berbeda dan dapat diandalkan untuk gambar bergerak. Situs ini sebenarnya tersedia bagi para tamu yang ingin mencari dan menonton informasi video secara langsung. Kami juga dapat mengunggah video ke server YouTube dan membagikannya ke seluruh dunia. Menurut (Dian, 2015, p. 47) situs web YouTube adalah video online dan terutama digunakan sebagai alat untuk menemukan, melihat, dan berbagi video asli dari seluruh penjuru dunia melalui web. 


\section{Perilaku Imitasi}

Perilaku dapat diartikan sebagai respons suatu organisme atau orang terhadap rangsangan eksternal (Notoatmodjo, 1993, p. 58). Secara sosial, imitasi adalah proses meniru perilaku orang atau pihak lain. Proses peniruan tidak bisa terjadi sendiri. Sebelum seseorang meniru atau meniru orang lain, pertamatama ia mengambil orang yang ditiru atau ditiru, mengagumi dan mempromosikan tinggi orang itu. Perilaku meniru atau meniru adalah tipikal anak-anak. Dalam meniru anak, orang tuanya dipandang sebagai sosok utama yang pantas ditiru sebelum meniru orang lain. Hampir semua kehidupan di awal usia anak didapatkan dari cara meniru. Karena anak belum memiliki pengalaman untuk memahami tujuan dari suatu perbuatan. Orang tua adalah model sang anak, karena apapun yang dicontohkan orang tua pada anak, itulah yang akan dilakukan oleh anak.

\section{Anak Usia Dini}

Menurut Susanto (Susanto, 2011, pp. 3-5) Anak usia dini usia 2-5 tahun umumnya keemasan, ini adalah tahap di mana anak-anak kritis terhadap semua perilaku baik atau buruk dari lingkungan. Idealnya orang tua tidak menyadari bahwa anak suka meniru berbagai hal mulai dari cara berbicara, tingkah laku pasti akan ditiru oleh anak karena orang tua yang menjadi panutan anak-anak dalam belajar meniru. Anak merupakan cerminan orang tua. Selain dari faktor intern (keluarga), anak juga bisa meniru dari media lain diantaranya; televisi, games playstation, internet, dan media sosial (salah satunya YouTube). Terutama pada usia diatas dua tahun, ego diri masingmasing anak belum bisa terkontrol dengan baik. Peran orang tua terhadap pola asuh ke anak harus diperhatikan dan sekaligus menjadi pengamat, pengawas dan pendidik. Berinisiatif untuk memanfaatkan aturan saat anak bermain, perbaiki tingkah laku anak jika tidak sesuai dengan aturan dengan memberikan nasehat, pencegahan, dan larangan yang baik. Jika anak pandai komunikasi verbal, pujilah anak untuk perilakunya yang baik. Selain itu, dunia anak-anak adalah dunia bermain, mereka bisa belajar sambil bermain.

Hipotesis

Hipotesis adalah jawaban sementara atas masalah penelitian, pandangan masih belum tentu benar (Kriyantono, 2016, p. 28). Atas dasar kerangka berpikir tersebut maka hipotesis dalam penelitian ini adalah: Ha: Adanya Pengaruh Terpaan Tayangan Animasi Nussa Official Episode Cuci Tangan Yuk di YouTube Terhadap Perilaku Imitasi Anak Usia 4-5 tahun Ho: Tidak adanya Pengaruh Terpaan Tayangan Animasi Nussa Official Episode Cuci Tangan Yuk di YouTube Terhadap Perilaku Imitasi Anak Usia 4-5

\section{Jenis Penelitian}

Pendekatan kuantitatif digunakan untuk penelitian ini. Metode penelitian merupakan dasar penelitian yang digunakan. Dengan tipe deskriptif.
Jenis penelitian eksplanatori adalah penelitian yang menghubungkan sebab dan akibat dari dua atau lebih konsep (variabel) yang akan diteliti (Kriyantono, 2016, p. 69).

\section{Definisi Operasional \\ Tabel Definisi Operasional}

\begin{tabular}{|c|c|c|}
\hline No. & Variabel & Indikator \\
\hline 1. & $\begin{array}{l}\text { Variabel } \\
\text { Independen } \\
(\mathrm{X}): \\
\quad \text { Terpaan } \\
\text { Tayangan } \\
\text { Animasi Nussa } \\
\text { Official } \\
\text { episode Cuci } \\
\text { Tangan Yuk }\end{array}$ & $\begin{array}{ll}\text { 1. } & \text { Frekuensi } \\
\text { 2. } & \text { Durasi } \\
\text { 3. } & \text { Intensitas }\end{array}$ \\
\hline 2. & $\begin{array}{r}\text { Variabel } \\
\text { Dependent (Y): } \\
\text { Perilaku } \\
\text { Imitasi Anak } \\
\text { usia 4-5 tahun }\end{array}$ & $\begin{array}{ll}\text { 1. } & \begin{array}{l}\text { Minat } \\
\text { (perhatian) }\end{array} \\
\text { 2. } & \begin{array}{l}\text { Retensi } \\
\text { (mengingat) }\end{array} \\
\text { 3. } & \begin{array}{l}\text { Reproduksi } \\
\text { Gerak }\end{array} \\
\text { 4. } & \text { Motivasi } \\
\end{array}$ \\
\hline
\end{tabular}

\section{Populasi dan Sampel}

Populasi penelitian ini adalah anak usia 4-5 tahun, baik laki-laki maupun perempuan, yang menonton Nussa Official dan tinggal di Kota Bekasi Utara. Dengan jumlah populasi sebanyak 3342 populasi yang diambil berdasarkan data dari UPP Kota Bekasi Utara. Sampel yang diterima sebanyak 97 orang.

\section{Teknik pengambilan sampel}

Dikarenakan jumlah populasi cukup banyak, agar mempermudah maka menggunakan presisi/estimasi $10 \%$ dari keseluruhan populasi dengan rumus slovin.

Rumus Slovin:

$n=\frac{N}{1+N e^{2}}$

$n=\frac{3342}{1+3334.10 \%^{2}}$

$n=\frac{3342}{1+3342.0 .01}$

$n=\frac{3342}{1+33.42}$

$n=\frac{3342}{34.42}$

$n=97$ sampel

\section{Teknik Pengumpulan Data}

Menurut Siregar (Siregar, 2015, p. 39) metode yang digunakan terdiri dari data primer dan sekunder, suatu teknik pengumpulan data yang sangat penting dalam penelitian.

- Data primer berupa hasil yang didapatkan atau diperoleh dari hasil lapangan. Sumber data 
tersebut bisa didapatkan dari hasil responden atau subjek penelitian dari hasil pengisian kuesioner atau angket dan observasi (Kriyantono, 2010, p. 41).

- Data sekunder, menurut (Kriyantono, 2010, p. 42) adalah data yang diperoleh dari sumber kedua untuk melengkapi data primer. Selain untuk melengkapi, data sekunder bisa digunakan apabila data primer sulit diperoleh. Pada penelitian ini, data sekunder yang didapatkan melalui YouTube Nussa Official dan beberapa literatur yang relevan.

\section{Alat pengukuran Data}

Skala likert dalam penelitian ini digunakan untuk mengukur sikap, pendapat dan persepsi seseorang atau kelompok terhadap fenomena sosial tertentu yang disebut variabel penelitian (Sugiyono, 2017, p. 146).

\section{HASIL DAN PEMBAHASAN}

Data responden pada penelitian ini adalah anak berusia 4-5 tahun yang diambil sampelnya sebanyak 97 orang. Berdasarkan kategori usia dan jenis kelamin, sebanyak $41 \%$ diisi oleh anak usia 4 tahun dan sisanya $56 \%$ diisi oleh anak usia 5 tahun. Hasil tersebut diketahui sebagian besar anak usia 4-5 tahun suka menonton tayangan Nussa Official.

\section{Hasil Uji Validitas dan Reabilitas}

Dalam penelitian ini, peneliti mencoba melakukan uji coba atau pre-test yang disebarkan kepada 30 responden dengan perhitungan melalui IBM SPSS 25. Pada uji validitas terdapat 11 item pernyataan pada variabel $\mathrm{X}$, yaitu "Pengaruh Terpaan Tayangan Animasi Nussa Official Episode Cuci Tangan Yuk di YouTube". Dari 11 item diperoleh masing-masing $r$ hitung $>r$ tabel sebesar 0,463 dengan nilai signifikansi $1 \%$ atau 0.01 maka dapat dikatakan valid. Untuk hasil uji validitas variabel Y "Perilaku Imitasi" terdapat 22 item diperoleh masing-masing $r$ hitung $>\mathrm{r}$ tabel sebesar 0,463 dengan nilai signifikansi $1 \%$ atau 0.01 maka dapat dikatakan valid.

\section{Hasil Uji Reabilitas}

Pengambilan keputusan tersebut dinyatakan reliable apabila hasil perhitungan Alpha Cronbach lebih besar dari 0,6. Hasil Alpha Cronbachnya sebesar 0,828 dimana hasil tersebut lebih besar dari 0,6 sehingga dapat disimpulkan bahwa variabel $\mathrm{X}$ yaitu pengaruh terpaan tayangan animasi Nussa Official episode cuci tangan yuk di YouTube dinyatakan reliable. Dan untuk hasil Alpha Cronbachnya sebesar 0,925 di mana hasil tersebut lebih besar dari 0,6 sehingga dapat disimpulkan bahwa variabel $\mathrm{Y}$ yaitu perilaku imitasi anak usia 4-5 tahun dinyatakan reliable.

\section{Analisis Koefisien Korelasi}

Analisis korelasi adalah istilah yang menyatakan derajat hubungan liner atau searah yang artinya ada atau tidak keeratan hubungan antara variabel X (variabel independent) dan variabel $\mathrm{Y}$ (variabel dependent). Metode korelasi yang digunakan dalam penelitian ini adalah Pearson's Correlation Product Moment. Hasilnya jika nilai signifikansinya sebesar $0,000<0,05$ maka berkolerasi atau adanya Hubungan antara variabel $\mathrm{X}$ terhadap variabel $\mathrm{Y}$. Bentuk hubungan sebesar 0,427 bernilai positif. Untuk derajat hubungan pada pedoman koefisien korelasi diketahui nilai interval koefisien sebesar 0,427 dimana nilai tersebut berada pada wilayah hubungan yang sedang. Jika bentuk hubungannya searah, maka variabel X "Pengaruh Terpaan Tayangan Animasi Nussa Official episode cuci tangan yuk di YouTube" naik dan variabel Y "Perilaku Imitasi" juga naik.

\section{Uji Regresi Linier Sederhana}

Diketahui konstanta dari hasil analisis regresi antara variabel bebas yaitu Pengaruh Terpaan Tayangan Animasi Nussa Official episode Cuci Tangan Yuk di YouTube dengan variabel terikat Perilaku Imitasi Anak usia 4-5 tahun diperoleh persamaan regresinya sebagai berikut: $\mathrm{Y}=46,328+$ 0,797X. Maka dapat disimpulkan bahwa setiap penambahan $1 \%$ pada variabel $X$ "Pengaruh Terpaan Tayangan Animasi Nussa Official episode Cuci Tangan Yuk di YouTube terhadap variabel Y "Perilaku Imitasi Anak usia 4-5 tahun" akan meningkat sebesar 0,797 pada arah positif dengan konstanta 46,328. Dengan demikian, variabel terikat akan mengalami penurunan bila variabel bebas mengalami penurunan karena variabel bebas berpengaruh kuat terhadap variabel terikat atau dengan kata lain Terpaan Tayangan animasi Nussa Official pada episode Cuci Tangan Yuk di YouTube berpengaruh kuat pada perilaku imitasi anak usia 4-5 tahun Kota Bekasi Utara.

\section{Koefisien Determinasi}

Koefisien determinasi adalah kuadrat dari koefisien korelasi yang menentukan atau menggambarkan kontribusi satu atau lebih variabel $\mathrm{X}$ terhadap variabel Y (Siregar, 2015, p. 338). Diperoleh koefisien determinasi ( $R$ Square) sebesar 0,182 pengertiannya adalah "pengaruh terpaan tayangan animasi Nussa Official episode cuci tangan yuk di YouTube" terhadap "perilaku imitasi anak usia 4-5 tahun" adalah sebesar 18,2\%.

\section{Uji Hipotesis}

Didapati nilai $\mathrm{t}$ hitung sebesar 4.596 dan $\mathrm{t}$ tabelnya 1.984 dengan $\mathrm{df}=97-2=95$; dengan nilai signifikansi 0.025. Artinya nilai t hitung $>\mathrm{t}$ tabel. Artinya bahwa Ho ditolak dan Ha diterima. Dapat disimpulkan bahwa Adanya Pengaruh Terpaan Tayangan Animasi Nussa Official episode Cuci Tangan Yuk di YouTube terhadap Perilaku Imitasi Anak usia 4-5 tahun Kota Bekasi Utara. 


\section{PENUTUP}

Berdasarkan pengolahan data, uraian teori, dan pengujian analisis data yang diperoleh melalui penyebaran kuesioner kepada 97 responden mengenai Pengaruh Terpaan Tayangan Animasi Nussa Official episode Cuci Tangan Yuk di YouTube terhadap Perilaku Imitasi Anak usia 4-5 tahun Kota Bekasi Utara, maka peneliti dapat simpulkan:

Dari hasil uji regresi dari Koefisien Determinasi ( $R$ Square) diketahui besarnya Pengaruh Terpaan Tayangan Animasi Nussa Official episode Cuci Tangan Yuk di YouTube terhadap Perilaku Imitasi Anak usia 4-5 tahun Kota Bekasi Utara adalah sebesar 18,2\% sementara 81,8\% lainnya dipengaruhi oleh faktor lain yang tidak diteliti dalam penelitian ini.

Berdasarkan uji hipotesis uji-t didapati nilai $\mathrm{t}$ hitung sebesar 4,596 dan t tabelnya 1.984 dengan $\mathrm{df}=$ 95 (jumlah data) n-2 maka dihasilkan 97-2=95; 0.025 (nilai signifikansi), artinya 4,596 > 1,984. Artinya bahwa Ho ditolak dan $\mathrm{Ha}$ diterima. Dapat disimpulkan bahwa Adanya Pengaruh Terpaan Tayangan Animasi Nussa Official episode Cuci Tangan Yuk di YouTube terhadap Perilaku Imitasi Anak usia 4-5 tahun di Bekasi Utara.

Penelitian ini diharapkan dapat menjadi bahan pertimbangan khususnya untuk The Little Giantz dan rumah produksi Empat Stripe Production dalam memproduksi film animasi Nussa Official untuk mengevaluasi lagi agar semakin baik dan meningkatkan kualitas agar anak-anak di Indonesia tidak hanya menonton tayangan saja namun ada pesan edukasi yang dapat diterapkan dikehidupan sehari-hari.

Saran teoritis untuk pengembangan penelitian agar melakukan teori yang berbeda seperti teori uses and gratification, atau stimulus-respon, teori sikap agar mendapatkan hasil terbaik. Lebih lanjut, sejauh pengaruh pemaparan tayangan animasi terhadap perilaku imitasi masa kanak-kanak, Anda dapat menggunakan Pendekatan Kuantitatif dengan wawancara mendalam atau Diskusi Kelompok Fokus untuk menentukan populasi yang berbeda, melainkan untuk meringkas hasil seperti yang diharapkan dalam tujuan atau hipotesis. Saran menyajikan hal-hal yang harus dilakukan sehubungan dengan ide penelitian selanjutnya.

\section{REFERENSI}

Adi, B. (2009). Panduan Praktis Searching di Internet. Jakarta: TransMedia.

Bandura, A. (1997). Self-Efficacy, The Exercise of Control. New York: W.H. Freeman and Company.

Bovee, C. L., \& Arens, W. F. (1995). Stock Image Contemporary Advertising (2nd ed.). USA: Gigabooks.

Cangara, H. (2015). Pengantar Ilmu Komunikasi (cetakan ke). Jakarta, 13220: PT. RajaGrafindo Persada.

Dian, B. (2015). Berkomunikasi Ala Net Generation. Jakarta, 13220: PT. Elex Media Komputindo Kompas Gramedia.

Effendy, O. U. (2009). Ilmu Komunikasi teori dan praktek. Bandung: Remaja Rosdakarya. Bandung: PT. Remaja Rosdakarya.

Fachruddin, H. D. (2011). Dasar-Dasar Penyiaran: Sejarah, Organisasi, Operasional, dan Regulasi (2nd ed.). Jakarta: Kencana Prenada Media Group. Retrieved from https://books.google.co.id/books/about/Dasar_d asar_Penyiaran_Sejarah_Organisasi.html?hl=id \&id=_IGWDwA AQABAJ\&redir_esc $=y$

Husamah, Y̌uni Pantiwati, Arina Restian, P. S. (2018). Belajar dan Pembelajaran (cetakan ke). Malang: UMM Press.

Khomsahrial, R. M. (2016). Komunikasi Massa. Jakarta, 13220: PT. Grasindo.

Kriyantono, R. (2006). Teknik Praktis Riset Komunikasi (edisi pert). Jakarta, 13220: KENCANA: PRENAMEDIA GROUP.

Kriyantono, R. (2010). Teknik Praktis Riset Komunikasi: Disertai Contoh Praktis Riset Media, Public Relations, Advertising, Komunikasi Organisasi, Komunikasi Pemasaran. Jakarta: Kencana Prenada Media Group.

Kriyantono, R. (2016). Teknik Praktis Riset Komunikasi. Jakarta: Kencana Prenada Media Group.

Liliweri, A. (2018). Paradigma Peneltian Sosial. Yogyakarta: Pustaka Pelajar.

Littlejohn, S. W dan Foss, K. A. (2018). Teori Komunikasi. Jakarta, 13220: Salemba Humanika.

Morrisan. (2010). Teori Komunikasi Massa. Bogor: Ghalia Indonesia.

Munir. (2012). Multimedia Konsep \& Aplikasi Dalam Pendidikan. (M. . Ruswandi dan Nurfitriansyah, Ed.), Antimicrobial agents and chemotherapy (pertama, Vol. 58). Bandung: ALFABETA.

Notoatmodjo, S. (1993). Pengantar Pendidikan dan Ilmu Perilaku Kesehatan. Yogyakarta: Andi Offset.

Nurhayati. (2020). Komunikasi Interpersonal Dalam Kegiatan Belajar Mengajar Antara Guru dan Murid Paud Joyce Banjarbaru. Jurnal Mutakallimin, 3(1), 23-27. Retrieved from https://ojs.uniska-

bjm.ac.id/index.php/mutakallimin/article/view/3 524

Nussa Official. (2019). Nussa: Cuci Tangan Yuk! Retrieved from https://www.youtube.com/watch?v=MzuKOouE $\mathrm{HnM}$

Rinawati, R. (2017). Pola Komunikasi dalam 
Pencegahan KDRT di Jawa Barat. Mediator: Jurnal Komunikasi, 10(1), 87-96. https://doi.org/10.29313/mediator.v10i1.2693

Siregar, S. (2015). Statistik Parametrik Untuk Penelitian Kuantitatif. Jakarta, 13220: Bumi Aksara.

Sugiyono. (2017). Metode Penelitian Kualitatif. Bandung: Alfabeta.
Susanto, A. (2011). Perkembangan Anak Usia Dini: Pengantar dalam Berbagai Aspeknya. (Y. Rendy, Ed.) (Pertama). Jakarta, 13220: EBOOK.

Tamburaka, A. (2012). Agenda Setting Media Massa. Jakarta, 13220: PT. RajaGrafindo Persada.

Wirawan, S. S. (1983). Pengantar Umum Psikologi. Jakarta: Bulan Bintang. 